\title{
Germination Response of Uniola latifolium
}

\author{
Michael R. Wade ${ }^{1}$ and D.F. Gilman \\ Department of Agronomy, Horticulture, and Agricultural Economics, \\ Tarleton State University, Stephenville, TX 16402
}

Additional index words. broadleaved uniola, potassium nitrate, temperature, prechilling

Abstract. Broadleaved uniola (Uniola latifolium Michx.) caryopses and florets were prechilled or not prechilled, supplied with potassium nitrate $\left(\mathrm{KNO}_{3}\right)$ or water only, and diurnal germination temperature alternations of $15 / 30 \mathrm{C}$ or $20 / 30 \mathrm{C}$ were used. Caryopses and florets both reached $50 \%$ germination by 10 days after planting with $\mathrm{KNO}_{3}$; however, in water, caryopses reached $50 \%$ germination significantly earlier than florets (18 vs. 30 days). Germination temperature and prechilling had no effect on days to $50 \%$ germination. Final germination percentages were significantly higher for caryopses than florets at both germination temperatures and for caryopses germinated at $15130 \mathrm{C}$ than at $20 / 30 \mathrm{C}(85 \%$ vs. $74 \%)$. Significantly more seeds germinated with $\mathrm{KNO}_{3}$ than in water $(85 \%$ vs. $57 \%)$. Prechilling had no effect on final germination percentage. Caryopses germinated with $\mathrm{KNO}_{3}$ at $15 / 30 \mathrm{C}$ achieved the highest final germination percentage.

Germination requirements for many species of grasses, such as broadleaved uniola, used increasingly in landscape plantings are not available. Studies of the grass species Miscanthus tinctorus (Steud.) indicated a benefit from prechilling the seeds at $\approx 3 \mathrm{C}$ for 3 months (Matumura and Yukimura, 1975). In the same study, fresh seeds of $M$. sacchariflorus (Maxim.) had lower germination rates at a constant $25 \mathrm{C}$, compared to seeds germinated at alternating temperatures of 20 and 30C. Germination rates of seeds under constant temperature reached those at alternating temperatures only after 195 days of prechilling. For shorter prechill periods, alternating between 20 and 30C gave higher rates of germination than use of a constant $25 \mathrm{C}$.

Weaver and Jordan (1985) showed that a low concentration $(0.02 \mathrm{M})$ of $\mathrm{KNO}_{3}$ may promote germination of A-68 Lehmann lovegrass (Eragrostis lehmanniana Nees.). Solutions of $0.1 \%$ to $0.2 \% \mathrm{KNO}_{3}$ are recommended by the Association of Official Seed Analysts (AOSA) and the International Seed Testing Association for germination tests of many species (Copeland and McDonald, 1985). Gadd (1955) showed that $\mathrm{KNO}_{3}$ increased the germination percent of New Zealand browntop ( Agrostis tenuis Sibth). The purpose of this study was to evaluate the effects of several seed treatments on germination of broadleaved uniola.

We collected seeds of broadleaved uniola from along the banks of the Bosque River in Erath County, Texas, during Fall 1985. Only

Received for publication 8 Mar. 1989. We express our gratitude to Dixie Ogle, Kay Helms, and Barbara Schmidt. The cost of publishing this paper was defrayed in part by the payment of page charges. Under postal regulations, this paper therefore must be hereby marked advertisement solely to indicate this fact.

${ }^{1}$ Associate Professor of Horticulture.

${ }^{2}$ Associate Professor of Agronomy. fully developed, plump, mature seeds were used. All seeds were stored at $22 \mathrm{C}$ and ambient relative humidity ( $25 \%$ to $30 \%$ ) until the test was initiated.

Seeds, visually selected for the study on the basis of size uniformity to minimize potential seed size effects, were divided into two equal samples, and caryopses were separated by hand from the lemma and palea of one sample. From each sample, 100 seeds were uniformly spaced in $9-\mathrm{cm}$ petri dishes onto three layers of filter paper serving as seed germination blotters in each of 32 petri dishes for caryopses and 32 for florets. The petri dishes of each seed treatment were subdivided into two equal subsamples; one-half was placed at $10 \mathrm{C}$ in darkness to chill for 2 weeks immediately before initiation of the study and the other half was held at room temperature in light (22C). Immediately before the test, each of the subsamples was divided into two equal parts, and the filter paper within the petri dishes was moistened with either $0.02 \mathrm{M} \mathrm{KNO}_{3}$ solution or distilled water. Germination was conducted according to the AOSA rules for testing (1981) at either of two diurnal temperature alternations-15C for $16 \mathrm{hr}$ and $30 \mathrm{C}$ for $8 \mathrm{hr}$ or $20 \mathrm{C}$ for $16 \mathrm{hr}$ and $30 \mathrm{C}$ for $8 \mathrm{hr}$. A Stultz Model 6EBSS-J392 (Stultz Scientific Engineering Corp., Springfield, Ill.) germination chamber was used for environmental control. Light was provided by four Sylvania Mainliner 40-W fluorescent tubes during the high-temperature cycle of each treatment. Gadd (1955) showed that light is important for uniform and fast germination and that the combination of light, $\mathrm{KNO}_{3}$, and alternating temperatures was essential for optimum germination in Agrostis tenuis.

A split-plot experimental design with four replications was used, with germination temperatures (15-20C, 20-30C) as main plots and treatment combinations, consisting of two seed classes (caryopses, florets), two pregermination temperatures $(10 \mathrm{C}, 22 \mathrm{C})$, and 
two germination pretreatments $\left(\mathrm{KNO}_{3}, \mathrm{H}_{2} \mathrm{O}\right)$, arranged factorially in a completely random design as subplots, a petri dish being a replicate. Seeds were considered germinated when the epicotyl and radicle had emerged and were counted four times weekly, beginning 5 days after planting and continuing until germination was complete 40 days after planting. Data were collected on days from planting until 50\% germination and final germination percentage. Standard arcsin square-root transformations were performed on the germination data before computing the analysis' of variance. Means were compared using Duncan's multiple range test (Steel and Torrie, 1980), and germination percentages were backtransformed for presentation:

Germination temperature had no effect on the, number of days from planting until $50 \%$ germination, with 17 days being required at both temperature regimes. All interactions involving temperatures also were not statistically significant, indicating that the temperatures used were well within the requirements of Uniola latifolium.

Prechilling tended to reduce 'the number of days from planting until $50 \%$ germination, requiring 16 days, as compared to 18 days for nonprechilled seeds. This difference, although of some practical importance for time conservation, was not significant, as were all interactions involving-prechilling.

Caryopses and florets did not differ significantly in days from planting until $50 \%$ germination when germinated in $\mathrm{KNO}_{3}$, requiring 9 and 10 days, respectively. However, when grown in water, caryopses reached $50 \%$ germination 18 days after planting, which was significantly $(P>0.01)$ earlier than the 30 days required for florets. Although the first-order interaction of seed Classes and pregermination treatments was. significant, none of the higher order interactions were.

Final germination percentages were significantly $(P>0.01)$ higher for caryopses than florets at both germination temperatures and for caryopses germinated at $15 / 30 \mathrm{C}(85 \%)$ than at 20/30C (74\%). Florets had a final germination of $63 \%$ at both temperatures. All other interactions involving seed classes and germination temperatures were not significant.

Seeds germinated with $\mathrm{KNO}_{3}$ had a final germination of $85 \%$, which was significantly $(P>0.01)$ higher than the $57 \%$ for seeds germinated in water. This trend was consistent for both prechilled and nonprechilled seeds and at both germination temperatures.

Prechilling had no effect on final germination percentage. Prechilled seeds averaged $73 \%$ germination, as compared to $71 \%$ for nonprechilled seeds. None of the interactions involving prechilling were significant, indicating that prechilling was not effective in promoting germination in this species.

From these studies, the optimum procedures for germination of broadleaved uniola seeds appear to be 1) removal of the caryopses from the lemma and palea and 2) germinating the caryopses for 2 weeks with
$\mathrm{KNO}_{3}$ at $15 / 30 \mathrm{C}$.

\section{Literature Cited}

Association of Official Seed Analysts. 1981. Rules for seed testing. J. Seed Technol. 6:2.

Cooeland, L.O. and M.B. McDonald. 1985. Seed germination. Principles of seed technology. 2nd ed. Burgess Publishing Co., Minneapolis. p. 55-101.

Gadd, I. 1955. Germination of seed of New Zealand browntop, Agrostis tenuis, Sibth. Proc. Intl.
Seed Testing Assn. 23:41.

Matumura, M. and T. Yukimura. 1975. Fundamental studies on artificial propagation by seedling useful wild grasses in Japan. Res. Bul. Faculty Agr. Gifu Univ. 38:339-349.

Steel; R.G.D. and J.H. Torrie. 1980. Principles and procedures of statistics. 2nd ed. McGrawHill, New York.

Weaver, L.C. and G.L. Jordan. 1985. Effects of selected seed treatment on germination rates of five range plants. J. Range Mgt. 38:5. 